\title{
MILITARY LEADERSHIP AND COMPETENCE-ORIENTED MENTORING IN THE PROFESSIONAL TRAINING OF FUTURE RESERVE OFFICERS
}

\section{ВІЙСЬКОВЕ ЛІДЕРСТВО ТА КОМПЕТЕНТНІСНО- ОРІСНТОВАНЕ НАСТАВНИЦТВО У ПРОФЕСІЙНІЙ ПІДГОТОВЦІ МАЙБУТНІХ ОФІЦЕРІВ ЗАПАСУ}

\section{Sergio Smirnov ${ }^{1}$}

DOI: https://doi.org/10.30525/978-9934-588-53-2-23

Abstract. The main purpose of the concept of transformation of domestic military education is to achieve an effective system of training in accordance with the need for training and development of future military specialists in terms of full compatibility of national military education with the military educational environment of Euro-Atlantic security space. Reforms aimed at Euro-Atlantic integration should lead to a change in the format from the training of future reserve officers, focused on career growth, to the direction of academic higher military education, in which the training of future military specialists will enable professional conversion to military activities and vice versa.

The research is devoted to the study of the state of professional training of future reserve officers in higher education institutions of Ukraine and on this basis to develop and test the effectiveness of methods aimed at improving the quality of pedagogical conditions on the basis of intensifying the content of professional training of future reserve officers. for the development of professional interest and competency-oriented mentoring, in order to quickly adapt young professionals to the conditions of the war environment, with the acquisition of the necessary basic professional experience.

The structure of readiness as a result of professional training of future reserve officers in higher education institutions is considered. Determined

\footnotetext{
${ }^{1}$ Honored Coach of Ukraine, Postgraduate Student of the Department of General Pedagogy and Preschool Education, Lesya Ukrainka Eastern European National University, Ukraine
} 
by the components of readiness of future reserve officers to carry out professional activities.

The constructed model of professional training of future reserve officers in higher education institutions is considered, which is described by means of target, theoretical-methodological, semantic, procedural and evaluationeffective subsystems and is directed on improvement of pedagogical conditions of professional military training of reserve officers in higher education institutions.

The modern requirements of military education related to Ukraine's integration into the European Union and into the NATO military-political alliance are taken into account.

The main attention is focused on the theoretical and methodological principles of adjusting the pedagogical conditions of professional training of future reserve officers on the basis of the formation of leadership competence and the logic of personal development on the basis of competence-oriented mentoring.

Mechanisms for intensifying the efforts of future reserve officers to strive to develop their professional knowledge and competencies, thus improving the ability of future military leaders to master the challenges of decisive action. Emphasis is placed on interpersonal communication skills, which link learning, creativity, and play an important role in the development of competent and confident military leaders. In turn, reserve officers, formed on the basis of the philosophy of military leadership and professionally trained under competence-oriented mentoring, will in the future train and develop their subordinates through competence-oriented mentoring and form cohesive professional teams, teaching them military standards based on military competencies. Intensification of content on the basis of these pedagogical conditions will quickly adapt future reserve officers to the conditions of military service, optimally compress and accelerate the development of professional knowledge, skills, maturity, conceptual and team skills.

\section{1. Ветуп}

У процесі аналізу термінологічного апарату, проведеного на основі дослідження психолого-педагогічної і наукової літератури, виявлені сутнісні характеристики педагогічних умов професійної підготовки майбутніх офіцерів запасу у закладах вищої освіти. На підставі теоретичного аналізу психолого-педагогічної, наукової літератури та інфор- 
маційних ресурсів мережі Інтернет подана характеристика основних понять дослідження. Уточнено поняття «професійна підготовка майбутніх офіцерів запасу», «педагогічні умови професійної підготовки майбутніх офіцерів запасу у закладах вищої освіти» та «готовність майбутніх офіцерів запасу до здійснення професійної діяльності».

Розроблено структуру готовності майбутніх офіцерів запасу до здійснення професійної діяльності, у якій вихідними для нас стали такі ii компоненти: мотиваційний, когнітивний, емоційно-вольовий, особистісно-оріснтований.

Розглянуті методи та напрямки дослідження щодо професійної підготовки майбутніх офіцерів запасу у закладах вищої освіти;

Побудована модель професійної підготовки майбутніх офіцерів запасу у закладах вищої освіти, яка описана за допомогою цільової, теоретико-методологічної, змістової, процесуальної та оціночно-результативної підсистем і спрямована на вдосконалення системи військової підготовки офіцерів запасу у закладах вищої освіти.

3'ясовані педагогічні умови професійної підготовки майбутніх офіцерів запасу закладах вищої освіти на основі інтенсифікації змісту професійної підготовки майбутніх офіцерів запасу за рахунок впровадження компетентнісно-орієнтованого наставництва та курсу «Військова наука і лідерство» у розділ «Організація та методика роботи 3 особовим складом» освітньо-професійної програми «Військова підготовка офіцерів запасу» для курсантів освітньо-кваліфікаційного рівня «бакалавр».

Визначено рівні сформованості готовності майбутніх офіцерів запасу до здійснення професійної діяльності; розглянутий розвиток професійного інтересу майбутніх офіцерів запасу на основі впровадження компетентнісно-орієнтованого наставництва, теорії і методики військового лідерства; розглянуто набуття досвіду майбутніми офіцерами запасу у процесі практичної підготовки на основі впровадження компетентнісно-орієнтованого наставництва, теорії і методики військового лідерства.

Вдосконалення якості педагогічних умов професійної військової підготовки майбутніх офіцерів запасу на основі навчання і виховання лідерської компетентності, зокрема техніки оцінки ефективності особистості у колективі, полягає в імплантації методів підвищення обі- 
знаності про когнітивні та емоційні процеси, в результаті яких приймаються рішення на основі формування рефлексивного мислення в умовах емоційних перешкод.

Інтенсифікація змісту професійної підготовки майбутніх офіцерів запасу у закладах вищої освіти спрямована нами на формування навичок мислення. Ця модифікація може бути проведена, не відволікаючись від оволодіння важливими технічними навичками. Теорія i методика військового лідерства повинна замінити деякі тактичні сценарії, що повторюються, адже відмінна тактика не компенсує відсутність сприйнятливого керівництва ні у процесі професійної військової підготовки офіцерів запасу, ні у майбутній їх практичній діяльності у військових підрозділах.

Основне завдання, яке ми поставили перед собою - це не як визначити необхідне лідерство, а як його культивувати, розвивати та підтримувати в системі професійної в підготовки майбутніх офіцерів запасу, адже якісне лідерство $є$ безпосереднім примножувачем бойової готовності та основним охоронцем військової організації. Наше завдання полягало в тому, щоб систематизувати хороший досвід лідерської практики у військовому середовищі, а не просто створити міцну теоретичну платформу.

\section{2. Компоненти готовності майбутніх офіцерів запасу}

Готовність майбутніх офіцерів запасу до здійснення професійної діяльності у контексті нашого дослідження виступає показником якості професійної підготовки, іiї системним результатом. Ми розглядаємо готовність майбутніх офіцерів запасу до здійснення професійної діяльності як інтегративне ядро професійної самореалізації офіцера запасу, що являє собою особистісне утворення i включає такі компоненти, як мотиваційний (мотиви, адекватні цілям та завданням професійної підготовки офіцера запасу), когнітивний (сукупність знань, необхідних для здійснення професійної діяльності), емоційно-вольовий (управління психологічними елементами переживань та почуттів, що забезпечуватимуть майбутнім офіцерам запасу долати труднощі в екстремальних умовах), особистісно-орієнтований (значущі для офіцера запасу здібності та якості особистості). 
Для сучасних досліджень характерно не тільки виокремлення мотиваційного компоненту готовності до здійснення професійної діяльності, але й визнання його пріоритетного значення, оскільки цей компонент, як правило, є першим у різних структурах готовності.

O. I. Москаленко тлумачить мотиваційний компонент професійної готовності як «пріоритетний засіб передачі смислових установок та ціннісних орієнтацій. Це професійно-значущі мотиви, установки і цінності, спрямованість на формування потреби в отриманні знань, навичок й умінь; розвиток інтересу до майбутньої професії; спонукання до розв'язання додаткових професійних завдань; розширення кругозору, що сприяє удосконаленню, саморозвитку та самоактуалізації особистості» [11, с. 116].

В. П. Мурашковська характеризує мотиваційний компонент професійної готовності як «внутрішня позиція, яка включає в себе професійно орієнтовані інтереси, нахили, уподобання, цінності молодої людини (інтерес до навчальної діяльності й позитивне ставлення до майбутньої професії)» [12, с. 260].

C. I. Фармачей визначає мотиваційний компонент професійної готовності як прагнення досягти високих результатів і майстерності в діяльності; воно виявляється у виборі складних завдань і прагненні їх виконати. При цьому успіх у будь-якій діяльності залежить не тільки від здібностей, навичок, знань, а й від мотивації досягнення, адже людина з високим рівнем мотивації досягнення, намагаючись отримати високі результати, настирливо працює заради досягнення поставлених цілей [14, с. 72].

Надія Борисенко визначає когнітивний компонент професійної готовності як «наявність сукупності знань і умінь, що є наслідком пізнавальної діяльності та характеризується обсягом спеціальних знань (широтою, глибиною, системністю), стилем мислення й у цілому є орієнтовною основою майбутньої професійної діяльності» [3, с. 132].

Марина Дяченко-Богун визначає когнітивний компонент професійної готовності як «оволодіння фундаментальними знаннями професійної спрямованості та застосування набутих знань у практичній професійній діяльності» [4, с. 60].

Світлана Кравець визначає когнітивний компонент професійної готовності як «базова компетентність з необхідними фаховими знан- 
нями, методичною обізнаністю, дослідницькими навичками, пізнавальною активністю» [8, с. 84].

С. Л. Рубінштейн тлумачить когнітивний компонент професійної готовності як положення про вирішальну роль знань і когнітивних структур у протіканні психічних процесів і поведінки людини, яке передбачає формування комплексу психолого-педагогічних, дидактико-технологічних і методичних знань [13, с. 96].

М. І. Дьяченко, Л. А. Кандибович характеризують емоційно-вольовий компонент професійної готовності як почуття, вольові процеси, що забезпечують успішний перебіг і результативність діяльності фахівця; емоційний тонус, емоційна сприйнятливість. Серед вольових якостей виділяють, зокрема, цілеспрямованість (керування в роботі певною метою), самовладання і витримка (збереження самоконтролю в будь-якій ситуації), наполегливість (тривале збереження зусиль при досягненні поставленої мети), ініціативність (готовність і вміння виявляти творчий підхід до вирішення проблем), рішучість (своєчасно приймати продумані рішення і без зволікань приступати до їх виконання), самостійність (відносна незалежність від зовнішніх впливів), самокритичність (вміння зауважувати свої помилки, неправильні дії та прагнення їх виправити) [5].

3 наукової позиції Л. В. Кондрашової, емоційно-вольовий компонент професійної готовності - «це почуття, вольові процеси, що забезпечують успішний перебіг і результативність діяльності майбутніх фахівців соціальної сфери; емоційний тонус, емоційна сприйнятливість, цілеспрямованість, самовладання, наполегливість, ініціативність, рішучість, самостійність, самокритичність, самоконтроль» [6].

В. В. Корнещук, Ю. О. Марар визначають емоційно-вольовий компонент професійної готовності як «володіння прийомами саморегуляції, усвідомлена готовність до професійного ризику, здатність переносити значні фізичні і нервово-психічні навантаження» [7, с. 63].

А. Н. Бистрюкова визначає особистісно-орієнтований компонент професійної готовності «як інтегральну характеристику саморозвитку особистості, що представлена сукупністю особистісних, професійних якостей і станів, які дають змогу майбутньому фахівцю успішно здійснювати професійну діяльність та вдосконалюватися в ній; як результат взаємодоповнюючих процесів - цілеспрямованого й керованого 
процесу формування готовності в загальній системі підготовки фахівців і процесу саморозвитку, особистісного становлення майбутнього фахівця» $[1$, с. 6$]$.

На думку В. І. Бобрицької, особистісно-орієнтований компонент професійної готовності - це «рефлексія здатності людини до самоаналізу, осмислення й переосмислення своїх предметно-соціальних відносин $з$ довколишнім світом, що $є$ необхідною складовою розвиненого інтелекту» [2, с. 18].

М. Т. Левочко розглядає особистісно-орієнтований компонент професійної готовності як «особистісні детермінанти професійної компетентності, що включають особистісно-етичні та індивідуально-професійні складові» $[9$, с. 34].

М. І. Лук'янова характеризує особистісно-орієнтований компонент професійної готовності як гнучкість мислення та поведінки, які передбачають самостійне перенесення раніше засвоєних знань, умінь, способів діяльності у нові ситуації, бачення проблеми, що виникає з різних рольових позицій, комбінування раніше відомих способів у нові. Велике значення мають розумова мобільність, здібність включати у нові взаємозв'язки вже відомий зміст, використовувати можливість вибору при розв'язанні проблем як у професійній діяльності, так і в повсякденному житті [10, с. 60].

3 огляду на викладене нами, визначеними компонентами готовності майбутніх офіцерів запасу до здійснення професійної діяльності $\epsilon$ наступні:

Мотивачійний, що включає мотиви потреб успішно виконувати професійні завдання, інтереси та вподобання до майбутньої професії, ідеали фахівця, вищі почуття, переконання в необхідності професії,прагнення і розуміння необхідності подолання труднощів, бажання досягти успіху і показати себе з кращого боку, у вибір складних завдань i прагнення їх виконати спрямованість на формування потреби в отриманні знань, навичок й умінь, розширення кругозору, що сприяє удосконаленню, саморозвитку та самоактуалізації особистості.

Когнітивний, який характеризується наявністю базових професійних компетенцій, а саме: наявністю сукупності знань і умінь, що $є$ наслідком пізнавальної діяльності та характеризується обсягом спеціальних знань (широтою, глибиною, системністю), стилем мислення, 
володінням фундаментальними знаннями професійної спрямованості та застосуванням набутих знань у практичній професійній діяльності, знанням професійних обов'язків, функцій, оцінкою їх суспільної значущості, умінням аналізувати ситуацію з метою реалізації професійних завдань, методичною обізнаністю, дослідницькими навичками, пізнавальною активністю, усвідомленням своїх можливостей та здібностей, володінням необхідним обсягом відповідної інформації, яка потрібна для цілеспрямованої діяльності в екстремальних умовах бойової обстановки.

Емоиійно-вольовий, що включає наступні психологічні якості: почуття, вольові процеси, що забезпечують успішний перебіг і результативність діяльності фахівця; емоційний тонус, емоційна сприйнятливість, цілеспрямованість, самовладання і витримка (збереження самоконтролю в будь-якій ситуації), наполегливість (тривале збереження зусиль при досягненні поставленої мети), ініціативність (готовність і вміння виявляти творчий підхід до вирішення проблем), рішучість (своєчасно приймати продумані рішення і без зволікань приступати до їх виконання), самостійність (відносна незалежність від зовнішніх впливів), самокритичність (вміння зауважувати свої помилки, неправильні дії та прагнення їх виправити), володіння прийомами саморегуляції, усвідомлена готовність до професійного ризику, гнучкість поведінки в небезпечних ситуаціях, здатність переносити значні фізичні і нервово-психічні навантаження в екстремальних умовах.

Особистісно-орієнтований, що являє собою результат процесу саморозвитку особистості, який представлений сукупністю особистісних, професійних якостей і станів, які дають змогу майбутньому фахівцю успішно здійснювати професійну діяльність та вдосконалюватися в ній, рефлексією здатності людини до самоаналізу, осмисленням й переосмисленням своїх предметно-соціальних відносин 3 довколишнім світом, що є необхідною складовою розвиненого інтелекту, гнучкістю мислення та поведінки, які передбачають самостійне перенесення раніше засвоєних знань, умінь, способів діяльності у нові ситуації, баченням проблеми, що виникає з різних рольових позицій, комбінуванням раніше відомих способів у нові, розумовою мобільністю, здібністю включати у нові взаємозв'язки вже відомий зміст, використовувати можливість вибору при розв'язанні проблем як у про- 
фесійній діяльності, так і в повсякденному житті, відповідальністю перед справою та людьми, добропорядністю, єдністю слова та діла, фізичним, психічним та моральним здоров'ям, освіченістю, загальнокультурною грамотністю, креативністю, контактністю, конструктивною взаємодією із зовнішнім світом шляхом отримання особистісно-значущого і адекватного вимогам соціуму результату професійної діяльності, що є процесом, котрий не обмежується змістом набутого досвіду, а грунтується на актуалізованому прагненні до особистісного та професійного зростання.

\section{3. Модель професійної підготовки майбутніх офіцерів запасу}

Розробляючи модель професійної підготовки майбутніх офіцерів запасу у закладах вищої освіти (далі - ЗВО), ми спиралися на розробки учених, які у своїх наукових дослідженнях розглядали такі питання: Джоваті Джухарі - розуміння військової педагогіки; Джармо Тоскалліо - військову педагогіку та дієву компетентність; Пол Херсі та Пол Харвуд Бланшар - теорію життєвого циклу лідерства; Роджер Джеймс Хаус - теорію шляхової мети ефективності лідера; Джон Френч основи соціальної влади; Джей Конгер - харизматичність виняткового лідерства; Даніель Големан, Річард Бояцис, Енн Маккі - командні емоційні реалії; Едар Пур'єр - дослідження у військовому характері та керівництві; Еліот Коен - солдати, державні діячі та лідерство у воєнний час; Джон Кіган - цінність та обмеження інтелекту у війні; Ентоні Мак Івор - переосмислення принципів війни; Карл Білдер - американські військові стилі у стратегії та аналізі; Джеймс Кузес - чому люди вимагають лідера; Руперт Сміт - мистецтво війни в сучасному світі; Чангія Ху - формальне наставництво у військових академіях; Конні Р. Ванберг, Джон Каммейер, Мюллер і Марк Марсезе - результати наставництва в програмах формального наставництва; Ернест і Шавна Фрайді - стратегічна відповідність формального наставництва; Бред Джонсон і Джин Андерсен - як зробити наставницьку роботу; Таммі Д. Аллен та Кімберлі Е. О’Брайен - організаційні залучення формальних програм наставництва; Джудіт Браун - оцінка потреб у навчанні як необхідність для розробки ефективних програм навчання; Ніколас Кларк - політика аналізу потреб у навчанні; Девід Колб - досвід як джерело навчання та розвитку; Дональд Кірпатрік - методики оцінки 
навчальних програм; Деніел Канеман - аналіз швидкого і повільного мислення; Джон Пассмор - роль коучингу і наставництва як досвіду галузевих знань; Джон Уітмор - призначення, принципи і практика коучингу та лідерства.

При створенні моделі ми виходили із загальнотеоретичних основ моделювання, відповідно до яких були визначенні такі характеристики: а) модель повинна складати комплексну систему взаємопов'язаних елементів (принципів, змісту, форм, методів, засобів, новітніх підходів, функцій), які при створенні педагогічних умов забезпечують якісну професійну підготовку майбутніх офіцерів запасу у 3ВО; б) структура моделі повинна створювати можливості контрою досягнень курсантів військових навчальних підрозділів ЗВО на всіх стадіях навчання у контексті готовності до професійної діяльності; в) модель повинна надавати можливості для активного втручання з метою своєчасної корекції процесу професійної підготовки майбутніх офіцерів запасу у ЗВО.

Модель описана за допомогою цільової, теоретико-методологічної, змістової, процесуальної та оціночно-результативної підсистем.

Соціальне замовлення спрямоване на військову підготовку громадян України за програмою офіцерів запасу, за умови відповідності спеціальностей, які вони мають або за якими здійснюється їх підготовка у закладі вищої освіти відповідно військово-обліковій спеціальності, за якою проводиться професійна підготовка офіцерів запасу.

Цільова підсистема визначається метою і завданням професійної підготовки майбутніх офіцерів запасу у ЗВО.

Метою є формування готовності майбутніх офіцерів запасу до здійснення професійної діяльності.

До завдань професійної підготовки майбутніх офіцерів запасу у ЗВО віднесено:

1. Збільшення військового корпоративного рекрутингу, стримування небажаних професійних і соціальних зусиль, підтримка професійних ініціатив, пришвидшення адаптації молодих фахівців у військовому середовищі.

2. Впровадження сучасних ідей, інновацій і технологій навчання і виховання, що відповідають вимогам європейського та світового рівнів, і реальною організацією навчального процесу. 
3. Створення умов для формування особистісних якостей офіцерів, що зумовлюють успішність діяльності, особливо в екстремальних умовах.

4. Формування у майбутніх офіцерів запасу раціональної системи знань, умінь і навичок, необхідних для подальшого спеціалізованого вдосконалення та високоефективного практичного застосування.

5. Формування постійної готовності виконувати своє професійне призначення в будь-який час і за будь-яких умов, у тому числі й за безпосереднього ризику для життя, що само по собі викликає постійне психологічне напруження.

6. Формування і розвиток у студентів військових кафедр професійно-педагогічного інтересу як основи їх творчої спрямованості в роботі 3 майбутніми (потенційними) підлеглими.

7. Формування потреб у сполученні управлінських функцій із передачею професійних знань, умінь і навичок іншим.

8. Інтенсифікація участі майбутніх офіцерів запасу у міжнародних навчаннях, тренувальних місіях, тренінгах, освітніх програмах, консультаціях, стажуваннях та інших подібних заходах.

9. Формування у майбутніх офіцерів запасу боєздатності, багатофункціональності, мобільності, професійної підготовленості належному рівні, які за своїми спроможностями будуть здатні ефективно виконувати завдання за призначенням.

10. Формування позитивного ставлення до професії, мотиваційного налаштування, якості особистості, процесуальної спрямованості особистості до певної діяльності, морально-вольових якостей особистості, рис характеру, здатності до засвоєння, способів поведінки, практичних умінь та навичок, внутрішньо особистісних утворень, професійно важливих пізнавальних процесів, проявів темпераменту, внутрішніх налаштувань та пристосувань особистості до успішних дій.

11. Формування у майбутніх офіцерів запасу спроможності володіти такою ситуацією, яка потребує від військового спеціаліста великої інтелектуальної напруги.

12. Формування високопрофесійних компетентностей з розвиненим творчим мисленням.

13. Формування умінь приймати оптимальні рішення в умовах постійної зміни обстановки та вмілого керування підпорядкованими йому підрозділами. 
14. Навчання вмінням приймати нестандартні рішення, творчо підходити до визначення оптимальних шляхів щодо подолання труднощів.

15. Навчання стратегії і тактиці ділової бесіди та публічного виступу, дотримання норм службової етики, психології та культури спілкування, знанням і вмінням застосовувати на практиці комунікативні методи та прийоми управлінського впливу.

16. Формування високої готовності до професійної самореалізації, аналізу, синтезу та умінь встановлювати причинно-наслідкові зв'язки, критичності та самокритичності, соціальної пластичності через толерантність, наявність лідерських та управлінських якостей.

17. Навчити майбутніх офіцерів запасу бути не лише фахівцем у певній сфері, але й цінителем кращих духовних надбань як свого народу, так і людства загалом, виховати толерантність, смак до мови, навчити сприймати ідеали рівності, справедливості і запроваджувати їх у життя.

18. Своєчасна ідентифікація та розв язання морально-психологічних та психофізичних проблем, що у свою чергу дасть змогу відповідною підтримкою мінімізувати групи ризику серед майбутніх офіцерів запасу.

Теоретико-методологічна підсистема визначається: 1) теоретичними підходами; 2) принципами.

До теоретичних підходів віднесено: особистісно-орієнтований, системний та діяльнісний.

Особистісно-орієнтований підхід дозволив підвищити у курсантів рівень освіченості та інтелектуальної діяльності на основі навчання $і$ виховання лідерської поведінки, яка є хорошим зразком для наслідування; сформувати три головні якості, які притаманні сучасному професійному військовому: компетентності, відповідальності і відданості своїй справі; сформувати відповідні знання, уміння та навички, які відповідають індивідуальним запитам особистості, суспільним потребам та світовим стандартам.

Системний підхід дозволив виділити складові готовності майбутніх офіцерів запасу до професійної діяльності.

Діяльнісний підхід дозволив організувати навчально-виховний процес у військових навчальних підрозділах ЗВО таким чином, щоб відбулося формування усіх компонентів готовності майбутніх офіцерів запасу. 
Нами було виокремлено такі принципи: зв'язку теорії з практикою, принцип свободи вибору, принцип особистісної цілеспрямованості, принцип вибору власної освітньої траєкторії, принцип індивідуальної адаптивності, принцип освітньої рефлексії.

Приниип зв'язку теорії з практикою реалізовувався шляхом створення а практичних заняттях педагогічних ситуацій, наближених до реальних умов здійснення майбутньої професійної діяльності.

Приниип свободи вибору передбачав право вибору курсантом додаткового консультування (наставництва), темпу, форм і засобів роботи. Ми не лише надавали курсантам свободу вибору, але й вчили їх діяти усвідомлено у ситуації вибору.

Принцип особистісної ијлеспрямованості курсантів забезпечував підготовку з урахуванням особистісних навчальних цілей. Майбутні офіцери запасу окреслювали проблеми, які їх цікавили, консультувалися з викладачем, узгоджували індивідуальну програму занять із загальною освітньою програмою.

Принщип вибору власної освітньої траєкторії реалізовувався у процесі усвідомленого та узгодженого з викладачем вибору курсантом теми творчої роботи, форми їі виконання та захисту.

Принцип індивідуальної адаптивності здійснювався через створення груп курсантів, подібних за рівнем готовності до професійної діяльності в екстремальних умовах. Сутність принципу - навчання кожного на рівні його індивідуальних можливостей і здібностей; адаптація навчального процесу до особливостей різних створених груп курсантів. Курсанти окреслювали проблеми, які їх цікавили, консультувалися з викладачем, узгоджували індивідуальну програму занять.

Принции освітньої рефлексї̈ реалізовувався супроводом освітнього процесу рефлексивним усвідомленням курсантів. Це було необхідною умовою того, щоб курсанти бачили схему організації діяльності, яка передбачає застосування лідерських компетенцій у військовому середовищі, конструювали власну лідерську позицію відповідно до своїх цілей і програм, усвідомлювали результати такої діяльності у роботі 3 особовим складом.

Змістова підсистема визначається: 1) структурними компонентами готовності майбутніх офіцерів запасу до здійснення професійної діяльності; 2) функціями; 3) педагогічними умовами; 4) система 
знань, умінь та навичок освітньо-професійної програми «Військова підготовка офіцерів запасу»; 5) впровадження дисципліни «Військова наука і лідерство» у розділ: «Організація і методика роботи з особовим складом»; 6) компетентнісно-оріснтоване наставництво, спрямоване на впровадження і реалізацію програм формального наставництва, орієнтованого на розвиток професійних компетенцій.

До структурних компонентів готовності майбутніх офіцерів запасу віднесено: когнітивний, емоційно-вольовий, мотиваційний, особистісно-орієнтований. Структурні компоненти готовності були розглянуті у першому розділі. До функцій віднесено: освітня, конструктивна, розвивальна, організаторська, комунікативна, гностична.

Освітня функція передбачає оволодіння майбутніми офіцерами запасу відповідної військово-облікової спеціальності грунтовними знаннями про військове лідерство з основним призначенням - на посадах офіцерського складу у військовому середовищі вміти організовувати і регулювати практичну індивідуальну та групову професійну діяльність на основі особистих професійних якостей, знань, умінь і практичних навичок військового фахівця.

Конструктивна функиія полягає у розвитку професійних здібностей майбутніх офіцерів запасу визначати мету військового лідерства, його бачення, переваги, спрямованість та мотивацію на основі філософії військового лідерства; у засвоєнні цінностей військової організації та очікуваної етики поведінки у військовому середовищі.

Розвивальна функиія забезпечує формування у курсантів трьох головних якостей, які притаманні сучасному професійному військовому: компетентності, відповідальності і відданості своїй справі.

Організаторська функиія реалізовує групові ефекти: особливості поведінки особистості у групі, характеризує команду та етапи іiі побудови, практичне застосування фахових компетенцій військового лідера; навчає основам і сутності влади, філософії партисипативного та фасилітативного управління; оволодіння експертними знаннями організації роботи з особовим складом, важливими аспектами теорій пріоритетів, успіху та бенчмаркінгу.

Комунікативна функиія передбачає розвиток основних життєвих навичок, пов язаних з комунікацією, етиці спілкування, зворотного зв язку, рішенню проблемних ситуацій, вирішенню конфліктів; нав- 
чання ментальній спритності, між персональній тактовності, основам дискусії та переконання

Гностична функиія передбачає оволодіння майбутніми офіцерами запасу теорією лідерства і методами впливу; розвитку знань про себе: навчання розвитку впевненості у собі та індивідуальних лідерських якостей; навчання критичному мисленню, оволодіння концепціями гнучкого та адаптивного лідерства, процесами прийняття рішень у військовій організації та під час бойових дій.

Педагогічними умовами визначено такі: 1) врахування цілісності структурних компонентів готовності майбутніх офіцерів запасу до здійснення професійної діяльності; 2) поетапність, структурна чіткість і змістова насиченість навчально-виховного процесу в умовах компетентнісно-орієнтованого наставництва.; 3) забезпечення спрямованості на максимальну професійну самореалізацію на основі оволодіння теорією і методикою військового лідерства.

Перша педагогічна умова - врахування цілісності структурних компонентів готовності майбутніх офіцерів запасу до здійснення професійної діяльності - дозволяла сконцентрувати усі свої зусилля на досягнення результату професійної підготовки майбутніх офіцерів запасу у закладах вищої освіти.

Друга педагогічна умова - поетапність, структурна чіткість і змістова насиченість навчально-виховного процесу здійснювалась за рахунок оволодіння курсантами грунтовних знань, умінь та навичок в умовах компетентнісно-орієнтованого наставництва із загальновійськової підготовки, вогневої підготовки, тактичної і тактико-спеціальної підготовки, військово-технічної підготовки, методики роботи з особовим складом, фахової спеціальної підготовки.

Третя педагогічна умова - забезпечення спрямованості на максимальну професійну самореалізацію майбутніх офіцерів, яка здійснювалась на основі теоретичного вивчення і практичного застосування теорії і методики військового лідерства, навичок його практичного ефекту; аналізу армійських цінностей, очікуваної етики поведінки та офіцерського досвіду; особистих викликів та компетенцій, що мають вирішальне значення для ефективного лідерства; розкриття особистих якостей життєвих навичок, а саме: спілкування, розуміння культури, встановлення цілей, управління часом, управління стресом та все- 
бічний фізичний фітнес; застосування активних навичок слухання $\mathrm{i}$ зворотного зв'язку; аналізу факторів, які впливають на ефективність лідерів і груп; вивчення етики командного мікроклімату; формування готовності до успіху внаслідок практичної лідерської відповідальності за задоволення у підлеглих духовних потреб; вивчення досвіду національного і зарубіжного успішного лідерства; методів консультування, принципів підлеглої мотивації та організаційних змін; вивчення практичного застосування принципів лідерства у складних ситуаціях на основі відтворення запропонованих тематичних симуляцій; вивчення основ прямого лідерства і його тактики у малому підрозділі.

Проиесуальна підсистема включає в себе етапи професійної підготовки майбутніх офіцерів запасу у закладах вищої освіти (діагностично-збагачувальний, репродуктивний, практично-творчий, оцінювальний); форми, методи і засоби підготовки майбутніх офіцерів запасу до професійної діяльності.

Теоретичний аналіз уможливив визначення діагностично-збагачувального, репродуктивного, практично-творчого та оцінювального етапів професійної підготовки майбутніх офіцерів запасу у закладах вищої освіти.

На діагностично-збагачувальному етапі забезпечувалося формування у курсантів професійних інтересів, мотивації до військової професії у майбутній професійні діяльності та важливості такої роботи.

На репродуктивному етапі забезпечувалося формування знань, умінь та навичок на основі інтенсифікації змісту професійної підготовки майбутніх офіцерів запасу впровадженням теорії і методики військового лідерства та в умовах застосування компетентнісно-орієнтованого наставництва.

На практично-творчому етапі відбувалось самоствердження і самореалізація курсантів під час практичного курсу розвитку та оцінки військового лідерства (англ. "Leadership Development and Assessment course $(L D A C)$ )» в польових умовах під час виконання навчально-бойових завдань (далі - НБЗ).

На оцінювальному етапі проведений аналіз ефективності змісту, форм, засобів і методів формування готовності майбутніх офіцерів запасу до здійснення професійної діяльності та надання рекомендацій щодо підвищення ефективності цього процесу. 
Формами визначено такі: лекції, семінарські, лабораторні (практичні), групові, індивідуальні заняття, самостійні заняття під керівництвом викладача і тактичні (тактико-спеціальні) заняття.

Методами $\epsilon$ : ситуативні моделювання прийняття рішень у військовій організації, ситуативно-аналітичні вправи, експрес-тестування, моделювання стресових ситуацій, інтерпретації невербальних сигналів, індивідуальна фізична підготовка.

Засобами є: навчально-методичний комплекс, навчальний посібник, мультимедійний супровід, Інтернет ресурси.

До результативно-підсумкової підсистеми входять критерії, показники та рівні сформованості компонентів готовності майбутніх офіцерів запасу до здійснення професійної діяльності.

Рівнями сформованості готовності майбутніх офіцерів запасу до здійснення професійної діяльності визначено низький, середній та високий.

Результатом є сформована готовність офіцерів запасу до професійної діяльності в умовах бойової обстановки.

\section{4. Інтенсифікація змісту підготовки майбутніх офіцерів запасу}

Запропонована робоча програма нормативної навчальної дисципліни «Військова наука і лідерство» розроблена на основі навчальної програми курсів: «Військова наука і лідерство» (англ. Courses (MILS) Military Science and Leadership), освітнього стандарту США за напрямком підготовки: «Військові науки: Офіцер резерву» (англ. Military Science: Army (ROTC) Reserve Officer Training Course) при цивільних закладах вищої освіти), де основна увага приділяється формуванню у курсантів трьох головних якостей, які притаманні сучасному професійному військовому: компетентності, відповідальності і відданості своїй справі.

Навчальна дисципліна «Військова наука і лідерство» розглядає розділ освітньо-професійної програми ЗВО з військової підготовки в Україні: «Організація і методика роботи з особовим складом» та спрямована на якісний розвиток вихідних компонентів готовності майбутніх офіцерів запасу до здійснення професійної діяльності, а саме: когнітивного, мотиваційного, особистісно-орієтованого, емоційно-вольового. 
Проведення занять пропонованого курсу вимагає застосування різноманітних методик. Важливим є здійснення проблемного підходу в лекційному викладанні, під час семінарських і лабораторних занять, в організації самостійної роботи. Доцільними є різні форми роботи курсантів: індивідуальна, диференційно-групова, фронтальна.

Курс «Військова наука і лідерство» включає в себе два модулі. У першому змістовому модулі «Базовий курс» (англ. «Basic Course») розкриваються методологічні та теоретичні основи фундаментальних концепцій і доктрини лідерства, практика його ефективних навичок, які лежать в основі вирішення проблем; аналізуються армійські цінності, очікувана етика поведінки та офіцерський досвід; розглядаються особисті виклики та компетенції, що мають вирішальне значення для ефективного лідерства та спілкування; курсанти дізнаються, як розкриваються особисті якості життєвих навичок, таких як розуміння культури, встановлення цілей, управління часом, управління стресом та всебічний фізичний фітнес, пов'язані з керівництвом, посадовими обов'язками та професією військового; розкривається застосування активних навичок слухання і зворотного зв'язку; проводиться аналіз факторів, яки впливають на ефективність лідерів і груп.

У другому змістовому модулі «Розширений курс» (англ. «Advanced Course») вивчається історія українського війська від давньослов янської цивілізації до сучасності; вивчається етика командного мікроклімату; формується готовність до успіху внаслідок практичної лідерської відповідальності за задоволення у підлеглих духовних потреб; розкриваються принципи і методи письмового і усного спілкування; вивчається досвід національного передового успішного лідерства; проводиться аналіз обов `язків і методів консультування, принципів підлеглої мотивації та організаційних змін; вивчається практичне застосування принципів лідерства у складних ситуаціях на основі практичного відтворення запропонованих тематичних симуляцій; вивчаються основи лідерства прямого рівня та тактики малого підрозділу на рівні взводу; здійснюється цілеспрямована комплексна фізична підготовка для відповідності і переваги стандартів фізичної підготовки, встановлених Збройними Силами України.

Навчальна програма розвитку лідерства «Військова наука і лідерство» - це попередній перегляд існуючої системи оцінки військових 
співробітників що триває, попередня оцінка ефективності майбутніх офіцерів запасу як потенційних лідерів військових підрозділів Збройних Сил України.

Розвиток військового лідерства ми розглядаємо як:

1. Як процес, розвиток лідера здійснюється як «розгортання» вже наявних, але «згорнутих» до пори властивостей даної цілісності, або «зародження» і становлення нових властивостей.

2. Як стан, розвиток лідера проявляється у процесі діяльності, спрямованої на виникнення якісно нових стабільних емоцій, в результаті чого відбувається якісна зміна і оновлення всієї цілісності особистості.

3. Як інтегративний творчий процес свідомого особистісного становлення, який заснований на взаємодії внутрішніх і зовнішніх факторів, для яких характерні доцільна внутрішня активність і усвідомлена спрямованість на формування, розгортання і вдосконалення значущих для людини властивостей, сторін і якостей, відсутніх раніше.

4. Модель розвитку військового лідера повинна бути побудована із спрямованістю на процес і результат у пропорції 50:50. Тобто, досконала професійна діяльність є тоді досконалою, коли в ній однаково добре розвинені і процеси, і присутні стійкі позитивні результати. Протиставляти процес і результат - неправильно. У справі досягнення будь-якої мети важливо і те, і інше.

Основна мета наставництва у військовій освіті - професійне становлення молодого військового фахівця, його активної життєвої позиції разом з формуванням його як особистості, як індивідуальності, а потім як офіцера запасу, який володіє спеціальними знаннями і вміннями у військовій галузі за певним видом професійної діяльності.

Основні завдання компетентнісно-орієнтованого наставництва:

1.Привити майбутнім офіцерам запасу інтерес до військової служби.

2. Сприяти успішній адаптації молодих фахівців до корпоративної культури, правилам поведінки у військовому середовищі.

3.Пришвидшити процес професійного становлення майбутнього офіцера запасу, розвинути його здібності самостійно і якісно виконувати покладені на нього обов'язки. 


\section{5. Висновки}

Отже, для максимально ефективної професійної самореалізації у військовій діяльності, майбутньому офіцеру запасу потрібно бути доброзичливим, справедливим, відповідальним, толерантним, емоційно стійким і водночас емпатійним, здатним прийти у будь-який момент на захист і допомогу. Саме ці особистісно-ціннісні людські характеристики офіцерів запасу під час квазіпрофесійної й власне професійної діяльності перетворюються у надзвичайно вартісні складові його професійної компетентності. Ми пояснюємо особливість таких трансформацій тим, що дана професія належить до соціономічного типу, тобто типу професій, де суб'єктом і об'єктом є людина. Тому, на нашу думку, вирішення концептуальних завдань 3 питань кадрового забезпечення сектору безпеки і оборони потребує переосмислення педагогічних умов професійної підготовки майбутніх офіцерів запасу, а саме в умовах формування лідерських компетенцій і наставництва, орієнтованого на компетентнісний підхід, який передбачатимуть високий рівень діяльнісних та службово-бойових складових фахової військової підготовки, а також у максимально стислий термін адаптуватись та інтегруватись у професійному військовому середовищі.

Нова парадигма сучасної вищої військової освіти зумовлює інше бачення позиції майбутнього офіцеру запасу, яка спонукає шукати відповідні чинники на сьогодення і в стратегічній перспективі, серед яких визначальною в усій системі вищої військової освіти України повинна стати людинотворча функція зі створенням педагогічних умов для самовдосконалення особистості як курсантів, так і викладачів.

\section{Список літератури:}

1. Бистрюкова А. Н. Формування готовності до професійного саморозвитку майбутніх учителів початкових класів засобами проективної технології : автореф. дис. на здобуття наук. ступеня канд. пед. наук : спец. 13.00.04 «Теорія та методика професійної освіти». Ялта, 2009. 12 с.

2. Бобрицька В. І. Теоретичні і методичні основи формування здорового способу життя у майбутніх учителів у процесі вивчення природничих наук : автореф. дис. ... докт. пед. наук : спеціальність 13.00 .04 «Теорія і методика професійної освіти». Київ, 2006. 40 с.

3. Борисенко Н. Структурні компоненти готовності майбутніх учителів технологій до формування художньо-технічних умінь в учнів основної школи. Наукові записки [Кіровоградського державного педагогічного уні- 
верситету імені Володимира Винниченка]. Сер.: Педагогічні науки. 2014. Вип. 132. С. 129-134.

4. Дяченко-Богун М. Структурні компоненти готовності майбутніх учителів природничих дисциплін до реалізації здоров'язбережувальних технологій у закладах освіти. Педагогіка і психологія професійної освіти. 2015. № 3. С. 58-66.

5. Дьяченко М. И., Кандибович Л. А. Психологическая проблема готовности к деятельности. Мн. : Изд-во БГУ, 1976. 176 с.

6. Кондрашова Л. В. Моральна психологічна готовність студента до вчительської діяльності. Київ : Вища школа, 1987. 218 с.

7. Корнещук В. В., Марар Ю. О. Військова професійна діяльність і готовність до неї. URL: http://www.enpuir.npu.edu.ua/bitstream/123456789/17041/1/ Korneshchuk_Marar.pd

8. Кравець С. Суть і компоненти готовності педагогів до впровадження дистанційного навчання кваліфікованих робітників. Науковий вісник Інституту професійно-технічної освіти НАПН України. Сер. : Професійна педагогіка. 2016. № 12. С. 78-89.

9. Левочко М. Т. Наступність у професійній підготовці майбутніх фахівців економічної галузі в системі «коледж-університет» : автореф. дис. ... д-ра пед. наук : 13.00.04. Київ : НАУ, 2010. 40 с.

10. Лукьянова М. И. Психолого-педагогическая компетентность учителя. Педагогика. 2001. № 10. С. 56-61.

11. Москаленко О. І. Компоненти готовності авіаційних фахівців до виконання професійної діяльності. Вісник Житомирського держсавного університету імені Івана Франка. 2015. Вип. 1. С. 116-119.

12. Мурашковська В. П. Структурні компоненти готовності абітурієнтів до навчання у ВНЗ. Педагогіка формування творчої особистості у вищій $i$ загальноосвітній школах. 2016. Вип. 46. С. 257-262.

13. Рубинштейн С. Л. Проблемы общей психологии. Москва : Педагогика, 1973. $424 \mathrm{c}$.

14. Фармачей С. И. Взаимосвязь мотивационной структуры личности с мотивацией достижения успеха. Матеріали міжн. наук.-практ. конф. молодих науковців «Психологія сучасності: наука і практика». Одеса, 2004. С. 72-74.

\section{References:}

1. Bystryukova, A. N. (2009). Formuvannia hotovnosti profesiynoho samorozvytku mayibutnih uchyteliv pochatkowyh klasiv zasobamy proektywnoi technolohii [Formation of readiness for professional self-development of future primary school teachers by means of projective technology]. Avtoref. dys. na zdobuttiya nauk. stupeniya kand. ped. nauk: spec. 13.00.04. "Teoriya ta metodyka profesiynoyi osvity» - Author's abstract. diss. for the sciences. degree of Cand. ped. Sciences: Special. 13.00.04 «Theory and methods of vocational education», 12 p. (in Ukrainian)

2. Bobrycka, V. I. (2006). Teoretychni I metodychni osnowy formuvannia zdorovoho sposobu zhyttia u maybutnich uchyteliv u processi wywchennia pryrodnych- 
ych nauk [Theoretical and methodical bases of formation of a healthy way of life at future teachers in the course of studying of natural sciences]. Avtoref. dys. ... doct. pred. nauk: spec. 13.00.04. "Teoriya ta metodyka profesiynoyi osvity»-Author's abstract. diss. ... Dr. ped. Sciences: specialty 13.00.04 "Theory and methods of vocational education», 40 p. (in Ukrainian)

3. Borysenko, N. (2014). Strukturni komponenty hotovnosti maibutnich uchyteliv technolohiy do formuvannia chudozhnio-technichnych umin' w uchniv osnovnoi shkoly [Structural components of the readiness of future teachers of technology for the formation of artistic and technical skills in primary school students]. Naukovi zapysky Kirovohtads koho derzhavnoho universytetu imeni Volodymyra Vynnychenka - Scientific notes of Kirovohrad State Pedagogical University named after Volodymyr Vynnychenko, no. 132, pp. 129-134. (in Ukrainian)

4. Diachenko-Bohun, M. (2015). Strukturni komponenty hotovnosti maibutnich uchyteliv pryrodnychych dyscyplin do realizacii zdorovyazberezhuwalnych technolohiy u zakladach osvity [Structural components of readiness of future teachers of natural sciences to implement health technologies in educational institutions]. Pedahohika i psycholohiya profesiynoi osvity - Pedagogy and psychology of vocational education, no. 3, pp. 56-66. (in Ukrainian)

5. Dyachenko, M. I. (1976). Psichlogicheskaya problema gotovnosti k deyatel nosti [Psychological problem of readiness for activity]. Belorusskiy Gosudarstvenny Univesitet - Belarusian State University, 176 p. (in Russian)

6. Kondrashova, L. V. (1987). Moral'na psycholohichna hotovnist' studenta do vchytel's 'koi diyalnosti [Moral psychological readiness of the student for teaching]. Wyshcha shkola - High school, 218 p. (in Ukrainian)

7. Korneshchuk, V. V., Marar, Yu. O. Wiys`kova profesiyna diyal'nist' I hotovnist' do nei [Military professional activity and readiness for it]. Retrieved from: http://www.enpuir.npu.edu.ua/bitstream/123456789/17041/1/Korneshchuk Marar.pd [Accessed 06 February 2019].

8. Kravec', S. (2016). Sut' i komponenty hotovnosti pedahohiv do wprovadzhennia dystanciynoho navchannia kvalifikovanych robitnykiv [The essence and components of the readiness of teachers to implement distance learning of skilled workers]. Naukovyi wisnyk Instytutu profesiyno-technichnoi osvity NAPN Ukrainy - Scientific Bulletin of the Institute of Vocational Education of the National Academy of Pedagogical Sciences of Ukraine, no. 12, pp. 78-89. (in Ukrainian)

9. Levochko, M. T. (2010). Nastupnist' u profesiyniy pidhotovci maybutnich fachivciv ekonomichnoi haluzi v systemi «koledz-universytet» [Continuity in the professional training of future specialists in the economic field in the system «college-university»]. Avtoref. dys. ... d-ra ped. nauk: spec. 13.00.04. «Teoriya ta metodyka profesiynoyi osvity» - Author's abstract. diss. ... Dr. ped. Sciences: specialty 13.00.04 "Theory and methods of vocational education», 40 p. (in Ukrainian)

10. Lukiyanova, M. I. (2001). Psichologo-pedagogicheskaya kompetentnost' uchitelia [Psychological and pedagogical competence of a teacher]. PedagogikaPedagogy, no. 10, pp. 56-61. (in Russian)

11. Moskalenko, O. I. (2015). Komponenty hotovnosti aviaciynych fachivciv do vykonannia profesiynoi diyal nosti [Components of readiness of aviation spe- 
cialists to perform professional activity]. Visnyk Zhytomyrs 'koho derzhavnoho universytetu imeni Ivana Franka - Bulletin of Zhytomyr State University named after Ivan Franko, no. 1, pp. 116-119. (in Ukrainian)

12. Murashkovs'ka, V. P. (2016). Strukturni komponenty hotovnosti abituriyentiv do navchannia $\mathrm{u}$ VNZ [Structural components of the readiness of entrants to study at the university]. Pedahohika formuvannia tvorchoi osobystosti $u$ vyshchiy I zahal noosvitniy shkolach - Pedagogy of formation of creative personality in higher and general education schools, no. 46, pp. 257-262. (in Ukrainian)

13. Rubinshtein, S. L. (1973). Problemy obshchey psichologii [Problems of General Psychology]. Pedagogika - Pedagogy, 424 p. (in Ukrainian)

14. Farmachey, S. I. Vzaimosviaz' motivacionnoy struktury lichnosti s motivaciyey dostizheniya uspecha [The relationship of the motivational structure of personality with the motivation for success]. Materialy mizhn. nauk.-prakt. konf. molodych naukovciv «Psycholohiya suchasnosti: nauka I praktyka»-Materials of international scientific-practical. conf. of young scientists «Psychology of modernity: science and practice», pp. 72-74. (in Ukrainian) 